\title{
Differential Gene Expression in Age-Related Macular Degeneration
}

\author{
Denise J. Morgan and Margaret M. DeAngelis
}

Department of Ophthalmology and Visual Sciences, John A. Moran Eye Center, University of Utah School of Medicine, Salt Lake City, Utah 84132

Correspondence: margaret.deangelis@utah.edu

Gene expression is the first step in ascribing function between an associated gene and disease. Understanding how variation in a gene influences expression, particularly in tissues affected by the disease, may help elucidate what influences the phenotypic outcome of that disease. Previous studies of the genetics of age-related macular degeneration (AMD) have identified several risk factors, but have not yet bridged the gap between gene association and identifying a specific mechanism or function that is involved in the pathogenesis of AMD. Advances in genomic technologies, such as RNA sequencing (RNA-seq), single cell RNAseq, bilsulfite sequencing, and/or whole genome methylation, will be powerful tools for identifying genes/pathways that are differentially expressed in those with AMD versus those without AMD. These technologies should advance the field of AMD research so that appropriate preventive and therapeutic targets can be developed.

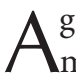
ge-related macular degeneration (AMD) is a multifactorial, complex disorder that affects the retinal pigment epithelium (RPE) with the accompanying loss of the overlying photoreceptors in the neural retina. The hallmark of AMD is the deposition of drusen, subretinal yellowish deposits accompanied by hypo- or hyperpigmentary changes of the RPE. The number, size, and area of drusen, along with the presence or absence of these pigmentary changes of the RPE, determine the severity of AMD in the early or intermediate stages (Ferris et al. 2005). These changes, which typically occur after the age of $40 \mathrm{yr}$, can occur in both the macula and extra macula but mostly concentrate in the macula (Curcio et al. 1996; Klein et al. 1997). The rea-
\end{abstract}

sons why are not entirely clear. As AMD is a progressive degenerative disease, having the intermediate stage puts one at risk for the advanced forms of the disease. Clinically, two forms of advanced AMD are recognized: geographic atrophy; and neovascular AMD. Geographic atrophy represents an area of loss of the RPE and choroid resulting in the gradual loss of photoreceptors. Neovascular or "wet" AMD is characterized by the growth of abnormal new blood vessels from the choroid into sub-RPE and subretinal regions and that can cause severe and rapid vision loss owing to hemorrhage and exudation. It is neovascular AMD that is responsible for the majority of debilitating vision loss because of AMD. Because the

Editors: Eric A. Pierce, Richard H. Masland, and Joan W. Miller

Additional Perspectives on Retinal Disorders: Genetic Approaches to Diagnosis and Treatment available at

www.perspectivesinmedicine.org

Copyright (C) 2015 Cold Spring Harbor Laboratory Press; all rights reserved; doi: 10.1101/cshperspect.a017210

Cite this article as Cold Spring Harb Perspect Med 2015;5:a017210 
macula is primarily affected, central vision loss results, with reduced quality of life manifesting as impaired ability to read, drive, and recognize faces. It is estimated that nearly 10 million U.S. citizens have some type of AMD in at least one eye, with the expectation that the contralateral eye will also be affected within 5 yr. Unfortunately, degeneration of the macula and/or the retina has generally begun by the time the patient is diagnosed with some form of AMD in the clinical setting. Additionally, most current treatments (which are directed against the advanced stage of AMD) are limited in their applicability and cannot reverse vision loss over the long term. Understanding which genes mechanistically underlie the pathophysiology of AMD could help us to identify biomarkers and/or predictors of disease onset, and to prevent progression to the intermediate and more advanced stages of AMD.

The genetic and epidemiological factors that contribute to overall AMD risk have been well studied, and it is likely that an individual's susceptibility to the disease is influenced by a combination of many different genetic and environmental factors (for reviews, see DeAngelis et al. 2011; Gorin 2012; Miller 2013; Fritsche et al. 2014). The architecture of AMD genetics has been expanded by the discovery of 19 loci associated with AMD with genome-wide significance (Fritsche et al. 2013) and the ongoing exome chip experiment efforts by the International AMD Genomics Consortium (IAMDGC) to identify rare AMD coding variants along with common variation. Consistently, ARMS2/ HTRA1 on chromosome 10q26 and CFH on chromosome 1q32 remain the most strongly associated loci with genetic risk of AMD (Fritsche et al. 2013). Whereas the role of complement factor $\mathrm{H}(\mathrm{CFH})$ in the complement pathway is well known, the roles of ARMS2/HTRA1 are not as clear. Based on efforts by the IAMDGC, the seven novel loci (COL8A1/FILIP1L, IER3/DDR1, SLC16A8, TGFBR1, RAD51B, ADAMTS9/MIR548A2, and B3GALTL), which reached genome-wide significance, strengthened our knowledge base from a genetic perspective. Common variation in these genes confirmed pathways and risk factors already associated with AMD pathogenesis, including collagen biogenesis (Zarbin et al. 2014), lipid metabolism (Pikuleva and Curcio 2014), cardiovascular risk factors (Chakravarthy et al. 2010), and apoptotic regulation (Payne et al. 2013). However, there remains a gap in our knowledge about the biological significance of these novel genes, as well as previously identified genes and their functions in AMD pathophysiology. From these genome-wide association (GWA) studies or candidate gene association studies, one can surmise what the function of a gene may be based on what tissues in which it is expressed, or if the gene has been associated with diseases with overlapping pathophysiology (e.g., cardiovascular disease or Alzheimer disease) (McKay et al. 2011; Cougnard-Grégoire et al. 2014; Klein et al. 2014; Logue et al. 2014). Given the limited resources of fresh human donor eye tissue for benchtop studies of gene expression, another approach is to use public databases (see Table 1) to determine tissue expression of a given gene. However, there is little information about how expression patterns differ between those with disease and those without, and whether or not

Table 1. Gene expression resources

\begin{tabular}{llc}
\hline Database & \multicolumn{1}{c}{ Website } & Eye tissue data sets \\
\hline Gene expression omnibus (GEO) & $\begin{array}{c}\text { http://www.ncbi.nlm.nih.gov/ } \\
\text { geo/ }\end{array}$ & $\begin{array}{c}\text { GEO:GSE29801 (Newman et al. } \\
\text { 2012), GEO:GSE40524 } \\
\text { (Farkas et al. 2013) }\end{array}$ \\
$\begin{array}{ll}\text { Serial analysis of gene expression (SAGE) } \\
\text { BioGPS }\end{array}$ & $\begin{array}{l}\text { http://cgap.nci.nih.gov/SAGE } \\
\text { http://biogps.org/ }\end{array}$ \\
RNA-seq atlas & http://medicalgenomics.org/ \\
rna_seq_atlas/data & \\
EMBL-EBI Expression atlas & http://www.ebi.ac.uk/gxa/home & \\
\hline
\end{tabular}


that pattern of expression differs between the various disease phenotypes. Studies of gene expression with regards to AMD phenotype are becoming increasingly important in assessing the relevance and possible functions of AMD risk loci and moving beyond genetic association to uncovering the specific pathways involved in the development and progression of the disease.

\section{CONSIDERATIONS FOR AMD GENE EXPRESSION STUDY SAMPLES}

Because AMD is a disease that affects the RPE/ choroid and the photoreceptors of the neural retina, these tissues should be the primary focus of gene expression studies in AMD. Ideally, tissues should be from both the macula and extra- macula regions of donor eyes with and without AMD (see Fig. 1). Moreover, because we do not know if this is a localized or systemic disease, venous blood samples collected from the donor of the eye tissue can also be useful in gene expression studies. Things to consider when conducting gene expression studies include the postmortem time, death-to-preservation time, how the tissue is dissected, which tissues to study (RPE/choroid and retina), postmortem ophthalmic imaging, and rigorous phenotyping. Furthermore, both ophthalmic records and medical records should be obtained whenever possible. As we have learned during our own experience from the creation of a fresh donor eye repository in the DeAngelis laboratory, many donor eyes have pathological signs of

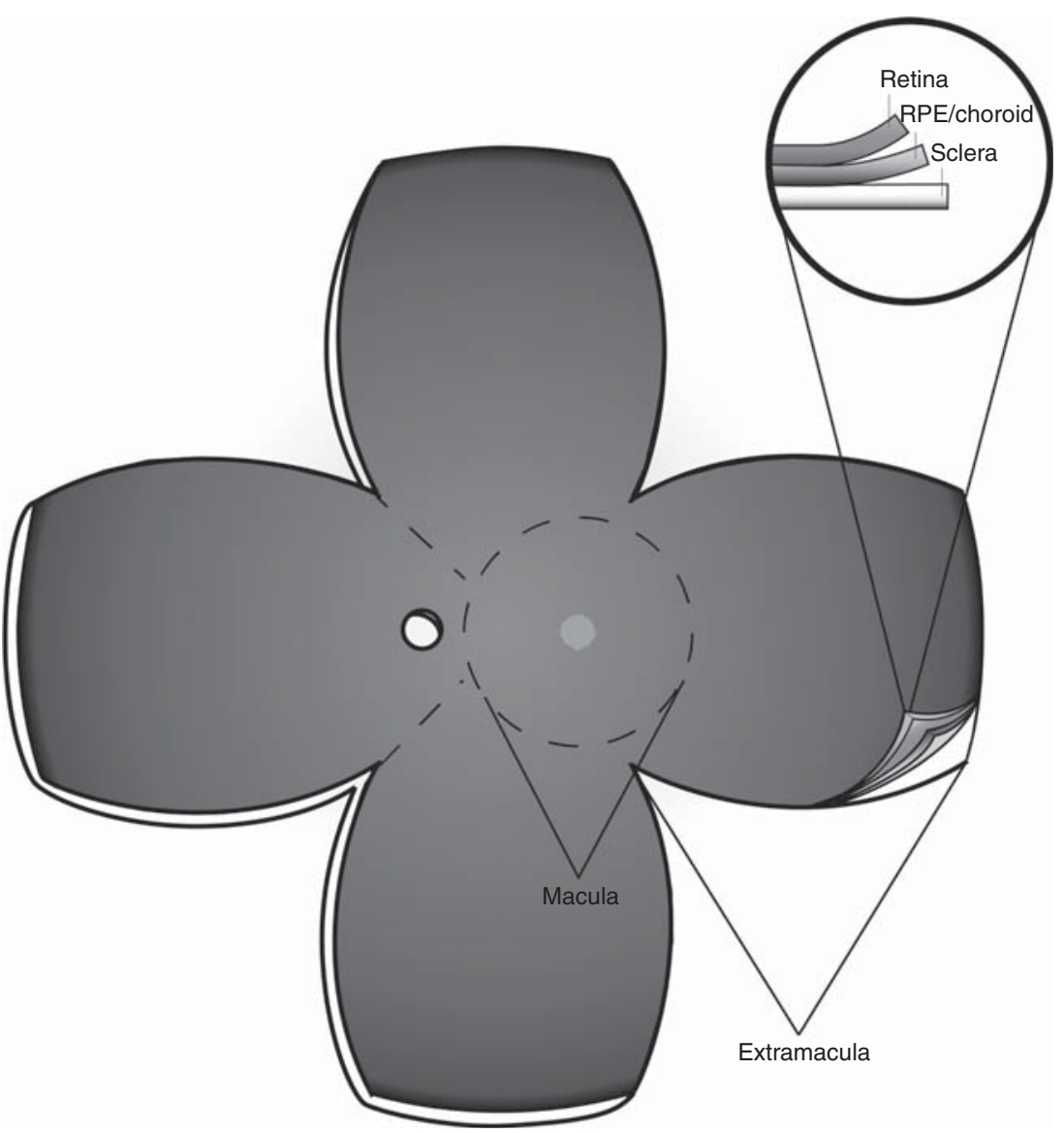

Figure 1. Geographical regions and tissue types isolated from human donor eye tissue for gene expression studies. 
AMD during postmortem imaging in one or both eyes that was not documented in available records. Additionally, many donors have discordant phenotypes between eyes.

\section{FACTORS AFFECTING GENE EXPRESSION IN AMD}

There are many factors that can affect the expression of a particular gene. Genetic variation, regulatory RNAs, and epigenetic modifications can all influence gene expression and have all been implicated in AMD pathophysiology.

\section{Genetic Variation}

The mechanisms by which AMD-associated genetic variations influence AMD risk are poorly understood. Because many of the AMD gene association studies published to date are GWA studies (Fritsche et al. 2013), and most of the variants that are investigated are tagging singlenucleotide polymorphisms (SNPs) or noncoding SNPs in large intergenic regions, it can be difficult to ascribe function to any particular associated variant. Coding variants located in the exons of genes usually have a predictable effect on the genes in which they are located. These variations can cause truncated or missense transcripts that can affect protein function or stability. To date, both common coding variations and rare coding variations have been reported in AMD-associated risk genes in the complement pathway (Edwards et al. 2005; Haines et al. 2005; Klein et al. 2005; Yates et al. 2007; Helgason et al. 2013; Zhan et al. 2013; Seddon et al. 2014; Yu et al. 2014). However, for AMD-associated variants that are coding, such as the ARMS2 A69S variant (Jakobsdottir et al. 2005; Rivera et al. 2005), it is not entirely clear how the variant affects the mRNA transcript or protein. Variations that modify gene expression are likely more important in the development of complex diseases such as AMD (Cookson et al. 2009; Silveira et al. 2010; DeAngelis et al. 2011).

When mRNA abundance is studied as a quantitative trait, it is possible to identify genetic variants that regulate gene expression. These expression quantitative trait loci (eQTLs) can influence gene expression at the level of transcription or translation (Majewski and Pastinen 2011), and act in cis (locally) or trans (distantly). SNPs located in promoter regions may affect gene expression at the level of transcription. In contrast, SNPs located in splice sites, miRNAs, or in miRNA-binding sites may have a posttranscriptional effect. A study by Lalonde and colleagues used RNA sequencing (RNA-seq) data from breast cancer cell lines, and concluded that the majority of eQTLs modify gene expression at the level of transcription, with $\sim 25 \%$ controlling their targets co- or posttranscriptionally (Lalonde et al. 2011).

To maximize their expression data, Li et al. (2014) integrated genetic variation data with expression data generated via RNA-seq. Specifically, they generated genotypes using a SNP chip on peripheral blood from each human eye donor to examine whether or not the previously identified SNPs also associated with ophthalmic diseases (including AMD), and showed allele-specific expression (ASE) in their RNA-seq data. Simply stated, the purpose of ASE analysis is to show which variants can regulate a gene in cis, using individuals who are heterozygous at a given SNP (Stevenson et al. 2013; Zhang et al. 2014). They identified three previously known common coding variants in the complement pathway that have also been associated with AMD risk (Fritshe et al. 2013). This shows that these disease-associated variants influence gene expression in tissues in which AMD is expected to manifest.

A few studies have looked at the effect of an AMD-associated SNP that lies in the promoter of HTRA1 (rs11200638) on gene expression. An early study on HTRA1 mRNA levels in blood lymphocytes found increased expression in individuals homozygous for the risk allele at rs11200638 (Yang et al. 2006). An additional study of cultured human RPE cells showed a twofold increase in HTRA1 expression for cells homozygous for the risk allele (An et al. 2010). However, the trend toward increased HTRA1 expression in relationship to the rs11200638 genotype was not seen in a study of human retina tissue. In fact, this study reported no observed differences in HTRA1 expression in human 
neural retina tissue with regards to age, AMD status, or genetic risk alleles (Kanda et al. 2010).

\section{Alternative Splicing}

Alternative splicing has been shown to be an important mechanism of gene expression regulation (Lalonde et al. 2011). A SNP located in a spice site can interfere with splice site recognition, preventing proper splicing and targeting a transcript for degradation (or otherwise blocking the translation of a particular transcript or splice variant). Although alternative splicing has been shown to occur in donor aging eye tissue of RPE/choroid/sclera (Li et al. 2014) and donor AMD retina (Karunakaran et al. 2013), it is still an understudied area in AMD pathophysiology.

\section{Noncoding RNAs (ncRNAs)}

Noncoding RNAs (ncRNAs) are involved in posttranscriptional gene modulation and are estimated to regulate translation of possibly $60 \%$ of protein-coding genes (for review, see Esteller 2011). ncRNAs also may provide a target for therapeutics in treating neurodegenerative, cardiovascular, and autoimmune diseases.

There are two primary classes of ncRNAs that can influence gene expression: microRNAs (miRNAs); and long intergenic noncoding RNAs (lincRNAs). miRNAs are generally 19 to 24 nucleotides in length and are important for posttranscriptional regulation of mRNA transcripts. It is estimated that they target up to a third of all human mRNAs, and are known to mediate their effect on mRNAs through translational repression or mRNA degradation ( $\mathrm{Ga}$ mazon et al. 2012). miRNAs are largely derived from introns of protein coding or noncoding genes. Mutations in the $2-8$ bp "seed" region of the mRNA binding site, located in the 3' UTR of the target gene, can prevent miRNA binding to target mRNA, likely resulting in increased target expression (Smith et al. 2012). Multiple studies have suggested a role for miRNA in AMD pathogenesis and as potential therapeutic targets (Lin et al. 2011; Haque et al. 2012; Hou et al. 2013; Zhou et al. 2014).
lincRNAs, as their name implies, are $>200$ nucleotides in length and have no coding capabilities. lincRNAs can interact with DNA, other RNAs, and/or proteins; furthermore, they may control transcriptional silencing via epigenetic regulation and chromatin remodeling. For example, in body fluids such as serum from patients with neuropsychiatric disorders, ncRNAs show altered expression when compared with controls, and therefore may be used as biomarkers to predict disease development (Mamdani et al. 2013). Similarly, for onset and progression of diseases such as AMD, miRNAs are proposed to be useful biomarkers (Hrdlickova et al. 2014) as they may be specific to body fluids.

\section{Epigenetics}

The definition of epigenetics refers to heritable changes in gene expression without changes to DNA sequence. Epigenetic regulation can involve processes such as DNA methylation, histone modification, and chromatin remodeling (Bock 2012; Heard and Martienssen 2014). There is increasing evidence that in complex diseases such as AMD, DNA methylation may contribute to gene expression variation (Petronis 2010). ncRNAs are abundant in the human genome and may be susceptible to environmental changes, and, through DNA methylation, ncRNAs can be involved in gene regulation by either silencing or up-regulating expression. Specifically, lincRNAs are believed to direct methylation to a specific gene (Peschansky and Wahlestedt 2014). Similar to gene expression patterns in tissues, methylation patterns can vary by tissue type, so patterns observed in peripheral blood from a patient with AMD may not translate to eye tissue. Moreover, methylation patterns that influence gene expression may differ between tissue subtypes within the posterior eye (e.g., RPE/choroid versus neural retina). Because the largest GWA study to date has yet to show a difference in genetic architecture between subtypes of AMD (Fritsche et al. 2013), it is possible that the differences in methylation could explain why the same genes are associated with different AMD phenotypes. 
Methylation levels generally decrease with aging (Bollati et al. 2009; Brunet and Berger 2014). This is not surprising, given that the effects of environmental factors, (such as nutrition, diet, medications, toxins, etc.) accumulate as we age. An example of this was demonstrated by showing that epigenetic factors control lipid variation. Specifically, methylation levels in carnitine palmitolytransferase $1 \mathrm{~A}$ were associated with fasting very low-density lipoprotein $\mathrm{C}$ and triglyceride levels in 991 middle aged adults. Further, this association was found to be independent of genetic variation (Irvin et al. 2014). In another study the quality and amount of dietary fat in one's diet could influence methylation of metabolic pathways. For example, by examining ratios of monounsaturated fatty acids, polyunsaturated fatty acids, and saturated fatty acids Voisin et al. (2014) showed that methylation of genes in several metabolic pathways including leptin was associated with overall fat intake but not cholesterol intake in preadolescents.

As oxidative stress is believed to be one of the mechanisms underlying AMD pathophysiology, Hunter et al. (2012) examined the glutathione S-transferase genes, GSTM1 and GSTM5, which function in detoxification and antioxidation. They used gene expression and methylation microarray data to show that GSTM1 and GSTM5 are differentially expressed in donor eyes with and without AMD and that this corresponds to changes in promoter methylation. Specifically, the mRNA levels of GSTM1 and GSTM5 were significantly reduced in donor eyes with AMD compared with age-matched controls in both the RPE/choroid and neural retina, which corresponded to hypermethylation of the GSTM1 promoter (Hunter et al. 2012). In another example of expression and methylation in peripheral blood from patients with AMD, Wei et al. (2012) found that hypomethylation in the promoter region of the interleukin 17 receptor C gene, IL17RC, correlated with up-regulation of IL17RC expression of mRNA in peripheral blood from a twin cohort with AMD. The up-regulation in IL7RC expression was also observed in retina and RPE/choroid from donor eyes with AMD. However, DNA methylation patterns from eye tissues were not examined, so, although expression pattern between peripheral blood and eye tissue could be correlated, methylation pattern status was not determined (Wei et al. 2012). Another study by Oliver and colleagues could not replicate these findings in peripheral blood from two cohorts comprised of unrelated case controls with and without AMD and concluded that decreased methylation in the IL7 RC promoter was not useful as a biomarker for AMD (Oliver et al. 2013). Ideally, future studies will need to incorporate RPE/choroid, neural retina and blood from the same donor into studies of both expression and methylation to elucidate mechanisms underlying normal aging compared with AMD. In this manner, appropriate therapeutic targets should begin to emerge.

\section{GENE EXPRESSION MICROARRAY AND RNA-seq STUDIES}

Microarray technology has been used in multiple studies to characterize the expression profiles of normal human eye tissues (Yoshida et al. 2002; Bowes Rickman et al. 2006; Radeke et al. 2007; Booij et al. 2010; Strunnikova et al. 2010; Zhang et al. 2012) and to identify genes that are differentially expressed both systemically, and in eye tissues of those with AMD (see Table 2) (Chowers et al. 2006; Radeke et al. 2007; Anderson et al. 2010; Silveira et al. 2010; Hunter et al. 2012; Newman et al. 2012). Notably, Silveira et al. (2010) used microarray analysis of lymphoblastoid cell line RNA from an extremely discordant sibling cohort to identify genes that are differentially expressed in neovascular AMD. They combined linkage and gene expression data to identify RAR-related orphan receptor A (RORA) as an AMD-associated gene that is expressed in lower levels in individuals with neovascular AMD compared with their unaffected siblings (Silveira et al. 2010). Also of note is a study by Newman and colleagues, who performed transcriptome analysis of AMD versus normal eye tissue. This study identified multiple genes differentially expressed in AMD tissues. Specifically, they showed overexpression of cell-mediated immune response genes in $\mathrm{RPE} /$ choroid from AMD eyes, overexpression 
Differential Gene Expression in AMD

Table 2. Studies of gene expression in AMD

\begin{tabular}{|c|c|c|c|c|}
\hline Study & Methodology & Sample source & $\begin{array}{l}\text { Death to } \\
\text { preservation }\end{array}$ & Molecules/pathways identified \\
\hline $\begin{array}{l}\text { Chowers } \\
\text { et al. } 2006\end{array}$ & Microarray & Retina tissue & Not provided & $\begin{array}{l}\text { Increased transferrin expression in } \\
\text { AMD vs. normal retina }\end{array}$ \\
\hline $\begin{array}{l}\text { Silveira et al. } \\
2010\end{array}$ & Microarray & $\begin{array}{l}\text { Lymphoblastoid cell } \\
\text { lines }\end{array}$ & Not applicable & $\begin{array}{l}\text { Decreased RORA expression in AMD } \\
\text { patients }\end{array}$ \\
\hline $\begin{array}{l}\text { Kurji et al. } \\
\quad 2010\end{array}$ & Microarray & Cultured RPE cells & Not applicable & $\begin{array}{l}\text { Differential expression of immune } \\
\text { response, inflammation, and } \\
\text { cytokine and interferon signaling } \\
\text { pathway genes in RPE cells } \\
\text { stimulated with A } \beta \text { 1-40, a } \\
\text { component of drusen }\end{array}$ \\
\hline $\begin{array}{l}\text { Newman } \\
\text { et al. } 2012\end{array}$ & Microarray & Retina and RPE tissue & $\begin{array}{l}\text { Iowa tissue: } 4 \mathrm{~h} \text {, } \\
\text { Oregon: } \\
<8.7 \mathrm{~h}\end{array}$ & $\begin{array}{l}\text { Overexpression of cell-mediated } \\
\text { immune response genes in RPE/ } \\
\text { choroid from AMD eyes, } \\
\text { overexpression of apoptosis genes } \\
\text { in GA and overexpression of genes } \\
\text { involved in angiogenesis in } \\
\text { neovascular AMD }\end{array}$ \\
\hline $\begin{array}{l}\text { Hunter et al. } \\
2012\end{array}$ & Microarray & Retina and RPE tissue & $\begin{array}{l}\text { Average } 5.2 \mathrm{~h} \\
\quad \text { (range } 2.5- \\
9.0 \mathrm{~h})\end{array}$ & $\begin{array}{l}\text { Reduced GSTM1 and GSTM5 } \\
\text { expression in AMD vs. normal }\end{array}$ \\
\hline $\begin{array}{c}\text { An et al. } \\
2010\end{array}$ & Targeted rt-pcr & Cultured RPE cells & Not applicable & $\begin{array}{l}\text { Increased HTRA1 expression in RPE } \\
\text { cells from individuals } \\
\text { homozygous for the risk allele at } \\
\text { HTRA1 promoter SNP } \\
\text { rs11200638 }\end{array}$ \\
\hline $\begin{array}{l}\text { Yang et al. } \\
\quad 2006\end{array}$ & Targeted rt-pcr & Blood lymphocytes & Not applicable & $\begin{array}{l}\text { Increased HTRA1 expression in } \\
\text { lymphocytes from individuals } \\
\text { homozygous for the risk allele at } \\
\text { HTRA1 promoter SNP } \\
\text { rs11200638 }\end{array}$ \\
\hline $\begin{array}{l}\text { Kanda et al. } \\
2010\end{array}$ & Targeted rt-pcr & Retina tissue & $<6 \mathrm{~h}$ & $\begin{array}{l}\text { No differential expression of ARMS2 } \\
\text { and HTRA1 in human retina with } \\
\text { regards to age, AMD status, or risk } \\
\text { alleles at chromosome } 10\end{array}$ \\
\hline $\begin{array}{l}\text { Tou et al. } \\
2004\end{array}$ & Targeted rt-pcr & $\begin{array}{l}\text { Paraffin-embedded } \\
\text { retina and RPE } \\
\text { tissue }\end{array}$ & Not applicable & $\begin{array}{l}\text { Decreased CX3CR1 expression in } \\
\text { AMD eyes }\end{array}$ \\
\hline $\begin{array}{l}\text { Anderson } \\
\text { et al. } 2010\end{array}$ & Targeted rt-pcr & $\begin{array}{c}\text { Retina, RPE, various } \\
\text { other tissue types }\end{array}$ & $0.5-6 \mathrm{~h}$ & $\begin{array}{l}\text { No differential expression of } \\
\text { complement genes in regards to } \\
\text { AMD status was detected. }\end{array}$ \\
\hline
\end{tabular}

of apoptosis genes in eyes with geographic atrophy (GA), and overexpression of genes involved in angiogenesis in neovascular AMD (Newman et al. 2012).

More recently RNA-seq has allowed examination of the transcriptome of the tissues that the disease affects in an unbiased manner. How- ever, unlike prior studies of traditional human gene expression, RNA-seq gives a more accurate assessment by measuring gene expression abundance. Moreover, RNA-seq can also assess the isoform structure of each gene, alternative splicing events, novel and rare transcripts, and the role of ncRNAs between disease phenotypes and 
tissue types relevant to gene function. Compared with traditional gene expression microarrays, RNA-seq also has a lower frequency of false-positive findings and a higher reproducibility as measured by validation because of less technical variation (Twine et al. 2011; Yendrek et al. 2012; Potok et al. 2013).

To date, only two studies have used RNA-seq to study eye tissue (Farkas et al. 2013; Li et al. 2014). Specifically, Farkas et al. (2013) examined retinal tissue from three donors in their 40s with normal phenotype as defined by no known ocular history. They identified 116 putative novel genes and $\sim 22,000$ alternative splice sites. $\mathrm{Li}$ et al. (2014) studied eight eyes over the age of $60 \mathrm{yr}$ defined as normal by phenotyping the fellow eye by retinal imaging, optical coherence tomography (OCT), and histological examination. Using RNA-seq they were able to show differential expression between the transcriptome of the neural retina and RPE/choroid/sclera.

At a minimum, the results generated from these studies have catalogued the transcribed mRNAs and novel genes of the neural retina and RPE/choroid/sclera specific to the normal eye as well as the normal aging eye. It will be important to see how this translates to the transcriptomic differences in the pathological eye with AMD and its subtypes as we and other laboratories are currently pursuing. The retina, RPE, and choroid are heterogeneous tissue composed of multiple cell types, including photoreceptors, Müller, microglial, and astrocytes (for reviews on the retina and RPE cellular composition, see Cepko 2012; Masland 2012). Single-cell RNA-seq (Shalek et al. 2014; Trombetta et al. 2014) will be needed to fully elucidate the biological variation in the complex cell types of these tissues. Conducting single-cell RNA-seq experiments on robustly defined AMD phenotypes and normal eyes will hopefully define the contributions of the cell types.

\section{SUMMARY}

In summary, gene expression studies in human eye tissue are an initial step in determining function for a putatively associated AMD risk gene. There are many challenges in obtaining and processing donor eye tissue. As discussed above, expression can be influenced by many factors, including methylation. Moreover, the most optimal study designs will include both peripheral blood and eye tissue from donors with and without AMD as well as robust phenotyping to pinpoint disease causality associated with a gene variant. These resources, combined with new genomic technologies, will help to identify therapeutic targets for the prevention and treatment particularly of the early forms of AMD.

\section{ACKNOWLEDGMENTS}

This work is supported by National Institutes of Health Grant EY-014458, the ALSAM Foundation, the Edward N. \& Della L. Thome Memorial Fund, Carl Marshall Reeves \& Mildred Almen Reeves Foundation, and an unrestricted grant from the Research to Prevent Blindness Foundation to the University of Utah Department of Ophthalmology and Visual Sciences.

\section{REFERENCES}

An E, Sen S, Park SK, Gordish-Dressman H, Hathout Y. 2010. Identification of novel substrates for the serine protease HTRA1 in the human RPE secretome. Invest Ophthalmol Vis Sci 51: 3379-3386.

Anderson DH, Radeke MJ, Gallo NB, Chapin EA, Johnson PT, Curletti CR, Hancox LS, Hu J, Ebright JN, Malek G, et al. 2010. The pivotal role of the complement system in aging and age-related macular degeneration: Hypothesis re-visited. Prog Retin Eye Res 29: 95-112.

Bock C. 2012. Analysing and interpreting DNA methylation data. Nat Rev Genet 13: 705-719.

Bollati V, Schwartz J, Wright R, Litonjua A, Tarantini L, Suh H, Sparrow D, Vokonas P, Baccarelli A. 2009. Decline in genomic DNA methylation through aging in a cohort of elderly subjects. Mech Ageing Dev 130: 234-239.

Booij JC, ten Brink JB, Swagemakers SMA, Verkerk AJMH, Essing AHW, van der Spek PJ, Bergen AAB. 2010. A new strategy to identify and annotate human RPE-specific gene expression. PLoS ONE 5: e9341.

Bowes Rickman C, Ebright JN, Zavodni ZJ, Yu L, Wang T, Daiger SP, Wistow G, Boon K, Hauser MA. 2006. Defining the human macula transcriptome and candidate retinal disease genes using EyeSAGE. Invest Ophthalmol Vis Sci 47: 2305-2316.

Brunet A, Berger SL. 2014. Epigenetics of aging and agingrelated disease. J Gerontol A Biol Sci Med Sci 69: S17-S20.

Cepko CL. 2012. Emerging gene therapies for retinal degenerations. J Neurosci Off J Soc Neurosci 32: 6415-6420. 
Chakravarthy U, Wong TY, Fletcher A, Piault E, Evans C, Zlateva G, Buggage R, Pleil A, Mitchell P. 2010. Clinical risk factors for age-related macular degeneration: A systematic review and meta-analysis. BMC Ophthalmol 10: 31 .

Chowers I, Wong R, Dentchev T, Farkas RH, Iacovelli J, Gunatilaka TL, Medeiros NE, Presley JB, Campochiaro PA, Curcio CA, et al. 2006. The iron carrier transferrin is upregulated in retinas from patients with age-related macular degeneration. Invest Ophthalmol Vis Sci 47: 2135-2140.

Cookson W, Liang L, Abecasis G, Moffatt M, Lathrop M. 2009. Mapping complex disease traits with global gene expression. Nat Rev Genet 10: 184-194.

Cougnard-Grégoire A, Delyfer M-N, Korobelnik J-F, Rougier M-B, Le Goff M, Dartigues J-F, Barberger-Gateau P, Delcourt C. 2014. Elevated high-density lipoprotein cholesterol and age-related macular degeneration: The Alienor study. PLoS ONE 9: e90973.

Curcio CA, Medeiros NE, Millican CL. 1996. Photoreceptor loss in age-related macular degeneration. Invest Ophthalmol Vis Sci 37: 1236-1249.

DeAngelis MM, Silveira AC, Carr EA, Kim IK. 2011. Genetics of age-related macular degeneration: Current concepts, future directions. Semin Ophthalmol 26: 77-93.

Edwards AO, Ritter R, Abel KJ, Manning A, Panhuysen C, Farrer LA. 2005. Complement factor $\mathrm{H}$ polymorphism and age-related macular degeneration. Science 308: 421 424.

Esteller M. 2011. Non-coding RNAs in human disease. Nat Rev Genet 12: 861-874.

Farkas MH, Grant GR, White JA, Sousa ME, Consugar MB, Pierce EA. 2013. Transcriptome analyses of the human retina identify unprecedented transcript diversity and $3.5 \mathrm{Mb}$ of novel transcribed sequence via significant alternative splicing and novel genes. BMC Genomics 14: 486.

Ferris FL, Davis MD, Clemons TE, Lee L-Y, Chew EY, Lindblad AS, Milton RC, Bressler SB, Klein R, AgeRelated Eye Disease Study (AREDS), et al. 2005. A simplified severity scale for age-related macular degeneration: AREDS Report No. 18. Arch Ophthalmol 123: $1570-1574$.

Fritsche LG, Chen W, Schu M, Yaspan BL, Yu Y, Thorleifsson G, Zack DJ, Arakawa S, Cipriani V, Ripke S, et al. 2013. Seven new loci associated with age-related macular degeneration. Nat Genet 45: 433-439, 439e1-2.

Fritsche LG, Fariss RN, Stambolian D, Abecasis GR, Curcio CA, Swaroop A. 2014. Age-related macular degeneration: Genetics and biology coming together. Annu Rev Genomics Hum Genet doi: 10.1146/annurev-genom-090413025610.

Gamazon ER, Ziliak D, Im HK, LaCroix B, Park DS, Cox NJ, Huang RS. 2012. Genetic architecture of microRNA expression: Implications for the transcriptome and complex traits. Am J Hum Genet 90: 1046-1063.

Gorin MB. 2012. Genetic insights into age-related macular degeneration: Controversies addressing risk, causality, and therapeutics. Mol Aspects Med 33: 467-486.

Haines JL, Hauser MA, Schmidt S, Scott WK, Olson LM, Gallins P, Spencer KL, Kwan SY, Noureddine M, Gilbert JR, et al. 2005. Complement factor $\mathrm{H}$ variant increases the risk of age-related macular degeneration. Science 308: 419-421.

Haque R, Chun E, Howell JC, Sengupta T, Chen D, Kim H. 2012. MicroRNA-30b-mediated regulation of catalase expression in human ARPE-19 cells. PLoS ONE 7: e42542.

Heard E, Martienssen RA. 2014. Transgenerational epigenetic inheritance: Myths and mechanisms. Cell 157: 95 109.

Helgason H, Sulem P, Duvvari MR, Luo H, Thorleifsson G, Stefansson H, Jonsdottir I, Masson G, Gudbjartsson DF, Walters GB, et al. 2013. A rare nonsynonymous sequence variant in $C 3$ is associated with high risk of agerelated macular degeneration. Nat Genet 45: 1371-1374.

Hou Q, Tang J, Wang Z, Wang C, Chen X, Hou L, Dong XD, Tu L. 2013. Inhibitory effect of microRNA-34a on retinal pigment epithelial cell proliferation and migration. Invest Ophthalmol Vis Sci 54: 6481-6488.

Hrdlickova B, de Almeida RC, Borek Z, Withoff S. 2014. Genetic variation in the non-coding genome: Involvement of micro-RNAs and long non-coding RNAs in disease. Biochim Biophys Acta doi: 10.1016/j.bbadis .2014.03.011.

Hunter A, Spechler PA, Cwanger A, Song Y, Zhang Z, Ying G-S, Hunter AK, Dezoeten E, Dunaief JL. 2012. DNA methylation is associated with altered gene expression in AMD. Invest Ophthalmol Vis Sci 53: 2089-2105.

Irvin MR, Zhi D, Joehanes R, Mendelson M, Aslibekyan S, Claas SA, Thibeault KS, Patel N, Day K, Waite Jones L, et al. 2014. Epigenome-wide association study of fasting blood lipids in the Genetics of Lipid Lowering Drugs and Diet Network Study. Circulation 130: 565572.

Jakobsdottir J, Conley YP, Weeks DE, Mah TS, Ferrell RE, Gorin MB. 2005. Susceptibility genes for age-related maculopathy on chromosome 10q26. Am J Hum Genet 77: 389-407.

Kanda A, Stambolian D, Chen W, Curcio CA, Abecasis GR, Swaroop A. 2010. Age-related macular degeneration-associated variants at chromosome 10q26 do not significantly alter ARMS2 and HTRA1 transcript levels in the human retina. Mol Vis 16: 1317-1323.

Karunakaran DKP, Banday AR, Wu Q, Kanadia R. 2013. Expression analysis of an evolutionarily conserved alternative splicing factor, Sfrs10, in age-related macular degeneration. PLoS ONE 8: e75964.

Klein R, Klein BE, Jensen SC, Meuer SM. 1997. The five-year incidence and progression of age-related maculopathy: The Beaver Dam Eye Study. Ophthalmology 104: 7-21.

Klein RJ, Zeiss C, Chew EY, Tsai J-Y, Sackler RS, Haynes C, Henning AK, SanGiovanni JP, Mane SM, Mayne ST, et al. 2005. Complement factor $\mathrm{H}$ polymorphism in age-related macular degeneration. Science 308: 385-389.

Klein R, Myers CE, Klein BEK. 2014. Vasodilators, blood pressure-lowering medications, and age-related macular degeneration: The Beaver Dam Eye Study. Ophthalmology 121: $1604-1611$

Kurji KH, Cui JZ, Lin T, Harriman D, Prasad SS, Kojic L, Matsubara JA. 2010. Microarray analysis identifies changes in inflammatory gene expression in response to amyloid-beta stimulation of cultured human retinal 
D.J. Morgan and M.M. DeAngelis

pigment epithelial cells. Invest Ophthalmol Vis Sci 51: 1151-1163.

Lalonde E, Ha KCH, Wang Z, Bemmo A, Kleinman CL, Kwan T, Pastinen T, Majewski J. 2011. RNA sequencing reveals the role of splicing polymorphisms in regulating human gene expression. Genome Res 21: 545-554.

Li M, Jia C, Kazmierkiewicz KL, Bowman AS, Tian L, Liu Y, Gupta NA, Gudsieva HV, Yee SS, Kim M, et al. 2014. Comprehensive analysis of gene expression in human retina and supporting tissues. Hum Mol Genet 23: 4001-4014.

Lin H, Qian J, Castillo AC, Long B, Keyes KT, Chen G, Ye Y. 2011. Effect of miR-23 on oxidant-induced injury in human retinal pigment epithelial cells. Invest Ophthalmol Vis Sci 52: 6308-6314.

Logue MW, Schu M, Vardarajan BN, Farrell J, Lunetta KL, Jun G, Baldwin CT, DeAngelis MM, Farrer LA. 2014. A search for age-related macular degeneration risk variants in Alzheimer disease genes and pathways. Neurobiol Aging 35: 1510.e7-e18.

Majewski J, Pastinen T. 2011. The study of eQTL variations by RNA-seq: From SNPs to phenotypes. Trends Genet TIG 27: 72-79.

Mamdani F, Martin MV, Lencz T, Rollins B, Robinson DG Moon EA, Malhotra AK, Vawter MP. 2013. Coding and noncoding gene expression biomarkers in mood disorders and schizophrenia. Dis Markers 35: 11-21.

Masland RH. 2012. The neuronal organization of the retina. Neuron 76: 266-280.

McKay GJ, Patterson CC, Chakravarthy U, Dasari S, Klaver CC, Vingerling JR, Ho L, de Jong PTVM, Fletcher AE, Young IS, et al. 2011. Evidence of association of $A P O E$ with age-related macular degeneration: A pooled analysis of 15 studies. Hum Mutat 32: 1407-1416.

Miller JW. 2013. Age-related macular degeneration revisited-Piecing the puzzle: The LXIX Edward Jackson memorial lecture. Am J Ophthalmol 155: 1-35.e13.

Newman AM, Gallo NB, Hancox LS, Miller NJ, Radeke CM, Maloney MA, Cooper JB, Hageman GS, Anderson DH, Johnson LV, et al. 2012. Systems-level analysis of agerelated macular degeneration reveals global biomarkers and phenotype-specific functional networks. Genome Med 4: 16 .

Oliver VF, Franchina M, Jaffe AE, Branham KE, Othman M, Heckenlively JR, Swaroop A, Campochiaro B, Vote BJ, Craig JE, et al. 2013. Hypomethylation of the IL17RC promoter in peripheral blood leukocytes is not a hallmark of age-related macular degeneration. Cell Rep 5: $1527-1535$.

Payne AJ, Kaja S, Sabates NR, Koulen P. 2013. A case for neuroprotection in ophthalmology: Developments in translational research. Mo Med 110: 429-436.

Peschansky VJ, Wahlestedt C. 2014. Non-coding RNAs as direct and indirect modulators of epigenetic regulation. Epigenetics 9: 3-12.

Petronis A. 2010. Epigenetics as a unifying principle in the aetiology of complex traits and diseases. Nature 465: 721-727.

Pikuleva IA, Curcio CA. 2014. Cholesterol in the retina: The best is yet to come. Prog Retin Eye Res 41C: 64-89.
Potok ME, Nix DA, Parnell TJ, Cairns BR. 2013. Reprogramming the maternal zebrafish genome after fertilization to match the paternal methylation pattern. Cell 153: 759772.

Radeke MJ, Peterson KE, Johnson LV, Anderson DH. 2007. Disease susceptibility of the human macula: Differential gene transcription in the retinal pigmented epithelium/ choroid. Exp Eye Res 85: 366-380.

Rivera A, Fisher SA, Fritsche LG, Keilhauer CN, Lichtner P, Meitinger T, Weber BHF. 2005. Hypothetical LOC387715 is a second major susceptibility gene for age-related macular degeneration, contributing independently of complement factor $\mathrm{H}$ to disease risk. Hum Mol Genet 14: 3227-3236.

Seddon JM, Reynolds R, Yu Y, Rosner B. 2014. Three new genetic loci (R1210C in $\mathrm{CFH}$, variants in COL8A1 and $R A D 51 B)$ are independently related to progression to advanced macular degeneration. PLoS ONE 9: e87047.

Shalek AK, Satija R, Shuga J, Trombetta JJ, Gennert D, Lu D, Chen P, Gertner RS, Gaublomme JT, Yosef N, et al. 2014. Single-cell RNA-seq reveals dynamic paracrine control of cellular variation. Nature 509: 363-369.

Silveira AC, Morrison MA, Ji F, Xu H, Reinecke JB, Adams SM, Arneberg TM, Janssian M, Lee J-E, Yuan Y, et al. 2010. Convergence of linkage, gene expression and association data demonstrates the influence of the RAR-related orphan receptor $\alpha$ (RORA) gene on neovascular AMD: A systems biology based approach. Vision Res 50: 698-715.

Smith RP, Lam ET, Markova S, Yee SW, Ahituv N. 2012. Pharmacogene regulatory elements: From discovery to applications. Genome Med 4: 45.

Stevenson KR, Coolon JD, Wittkopp PJ. 2013. Sources of bias in measures of allele-specific expression derived from RNA-sequence data aligned to a single reference genome. BMC Genomics 14: 536.

Strunnikova NV, Maminishkis A, Barb JJ, Wang F, Zhi C, Sergeev Y, Chen W, Edwards AO, Stambolian D, Abecasis G, et al. 2010. Transcriptome analysis and molecular signature of human retinal pigment epithelium. Hum Mol Genet 19: $2468-2486$.

Trombetta JJ, Gennert D, Lu D, Satija R, Shalek AK, Regev A. 2014. Preparation of single-cell RNA-seq libraries for next generation sequencing. Curr Protoc Mol Biol 107: 4.22.1-4.22.17.

Tuo J, Smith BC, Bojanowski CM, Meleth AD, Gery I, Csaky KG, Chew EY, Chan C-C. 2004. The involvement of sequence variation and expression of CX3CR1 in the pathogenesis of age-related macular degeneration. FASEB J. http://www.fasebj.org/content/early/2004/07/30/fj.041862fje (Accessed June 25, 2014).

Twine NA, Janitz K, Wilkins MR, Janitz M. 2011. Whole transcriptome sequencing reveals gene expression and splicing differences in brain regions affected by Alzheimer's disease. PLoS ONE 6: e16266.

Voisin S, Almén MS, Moschonis G, Chrousos GP, Manios Y, Schiöth HB. 2014. Dietary fat quality impacts genomewide DNA methylation patterns in a cross-sectional study of Greek preadolescents. Eur J Hum Genet doi: 10.1038/ejhg.2014.139.

Wei L, Liu B, Tuo J, Shen D, Chen P, Li Z, Liu X, Ni J, Dagur P, Sen HN, et al. 2012. Hypomethylation of the IL17RC 
promoter associates with age-related macular degeneration. Cell Rep 2: 1151-1158.

Yang Z, Camp NJ, Sun H, Tong Z, Gibbs D, Cameron DJ, Chen H, Zhao Y, Pearson E, Li X, et al. 2006. Avariant of the HTRA1 gene increases susceptibility to age-related macular degeneration. Science 314: 992-993.

Yates JRW, Sepp T, Matharu BK, Khan JC, Thurlby DA, Shahid H, Clayton DG, Hayward C, Morgan J, Wright AF, et al. 2007. Complement C3 variant and the risk of age-related macular degeneration. $N$ Engl J Med 357: $553-561$.

Yendrek CR, Ainsworth EA, Thimmapuram J. 2012. The bench scientist's guide to statistical analysis of RNA-Seq data. BMC Res Notes 5: 506.

Yoshida S, Yashar BM, Hiriyanna S, Swaroop A. 2002. Microarray analysis of gene expression in the aging human retina. Invest Ophthalmol Vis Sci 43: 2554-2560.

Yu Y, Triebwasser MP, Wong EKS, Schramm EC, Thomas B, Reynolds R, Mardis ER, Atkinson JP, Daly M, Raychaudhuri S, et al. 2014. Whole-exome sequencing identifies rare, functional $\mathrm{CFH}$ variants in families with macular degeneration. Hum Mol Genet doi: 10.1093/hmg/ ddu226.

Zarbin MA, Casaroli-Marano RP, Rosenfeld PJ. 2014. Agerelated macular degeneration: Clinical findings, histopathology and imaging techniques. Dev Ophthalmol 53: $1-32$.

Zhan X, Larson DE, Wang C, Koboldt DC, Sergeev YV, Fulton RS, Fulton LL, Fronick CC, Branham KE, BraggGresham J, et al. 2013. Identification of a rare coding variant in complement 3 associated with age-related macular degeneration. Nat Genet 45: 1375-1379.

Zhang Z, Zhang Y, Xiao H, Liang X, Sun D, Peng S. 2012. A gene expression profile of the developing human retinal pigment epithelium. Mol Vis 18: 2961-2975.

Zhang S, Wang F, Wang H, Zhang F, Xu B, Li X, Wang Y. 2014. Genome-wide identification of allele-specific effects on gene expression for single and multiple individuals. Gene 533: 366-373.

Zhou Q, Anderson C, Zhang H, Li X, Inglis F, Jayagopal A, Wang S. 2014. Repression of choroidal neovascularization through actin cytoskeleton pathways by microRNA-24. Mol Ther 22: 378-389. 


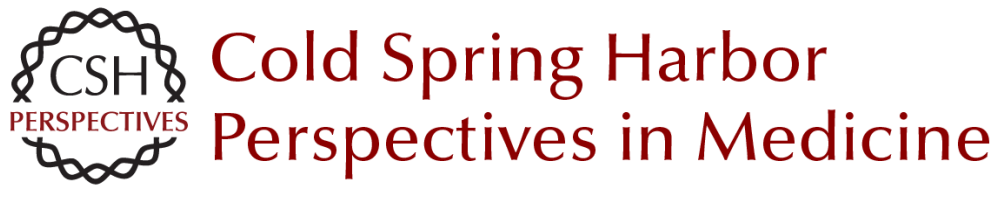

\section{Differential Gene Expression in Age-Related Macular Degeneration}

Denise J. Morgan and Margaret M. DeAngelis

Cold Spring Harb Perspect Med 2015; doi: 10.1101/cshperspect.a017210 originally published online October 23, 2014

\section{Subject Collection Retinal Disorders: Genetic Approaches to Diagnosis and Treatment}

Trial by "Firsts": Clinical Trial Design and Regulatory Considerations in the Development and Approval of the First AAV Gene Therapy Product in the United States Kathleen Z. Reape and Katherine A. High

Immunology of Retinitis Pigmentosa and Gene Therapy-Associated Uveitis

Paul Yang, Debarshi Mustafi and Kathryn L. Pepple

Developing New Vectors for Retinal Gene Therapy Emilia A. Zin, Bilge E. Ozturk, Deniz Dalkara, et al.

Beyond the NEI-VFQ: Recent Experience in the Development and Utilization of Patient-Reported Outcomes for Inherited Retinal Diseases

Todd Durham, Judit Banhazi, Francesco Patalano, et al.

Electronic Retinal Prostheses

Daniel Palanker

Alternative RNA Splicing in the Retina: Insights and Perspectives

Casey J. Keuthan, Sadik Karma and Donald J. Zack

X-Linked Retinoschisis

Cristy A. Ku, Lisa W. Wei and Paul A. Sieving

A Systematic Review of Optogenetic Vision Restoration: History, Challenges, and New Inventions from Bench to Bedside

Antonia Stefanov and John G. Flannery
Lessons Learned from the Development of the

First FDA-Approved Gene Therapy Drug,

Voretigene Neparvovec-rzyl Jean Bennett and Albert M. Maguire

Therapeutic Gene Editing in Inherited Retinal Disorders Jinjie Ling, Laura A. Jenny, Ashley Zhou, et al.

Cell-Based Therapies: Strategies for Regeneration Marina Pavlou and Thomas A. Reh

The Importance of Natural History Studies in Inherited Retinal Diseases

Allison Ayala, Janet Cheetham, Todd Durham, et al.

Photoreceptor Cell Replacement Using

Pluripotent Stem Cells: Current Knowledge and Remaining Questions

Christelle Monville, Olivier Goureau and Karim Ben M'Barek

iPSC-RPE in Retinal Degeneration: Recent

Advancements and Future Perspectives

Tadao Maeda and Masayo Takahashi

Retinal Degeneration Animal Models in Bardet-

Biedl Syndrome and Related Ciliopathies Clarisse Delvallée and Hélène Dollfus

Mobility Testing and Other Performance-Based Assessments of Functional Vision in Patients with Inherited Retinal Disease

Daniel Chung, Colas Authié and Laure Blouin

For additional articles in this collection, see http://perspectivesinmedicine.cshlp.org/cgi/collection/ 
For additional articles in this collection, see http://perspectivesinmedicine.cshlp.org/cgi/collection/ 